\title{
The Pirates At Tahiti in 1822: Two Unpublished Letters by Samuel Henry
}

\section{Rhys Richards}

\section{(2) OpenEdition \\ 1 Journals}

Electronic version

URL: http://journals.openedition.org/jso/5967

DOI: $10.4000 /$ jso. 5967

ISSN: $1760-7256$

Publisher

Société des océanistes

\section{Printed version}

Date of publication: 15 December 2009

Number of pages: 301-304

ISBN: 978-2-85430-026-0

ISSN: 0300-953x

\section{Electronic reference}

Rhys Richards, "The Pirates At Tahiti in 1822: Two Unpublished Letters by Samuel Henry », Journal de la Société des Océanistes [Online], 129 | juillet-décembre 2009, Online since 15 December 2009, connection on 24 September 2020. URL : http://journals.openedition.org/jso/5967 ; DOI : https:// doi.org/10.4000/jso.5967 


\section{The Pirates At Tahiti in 1822: Two Unpublished Letters by Samuel Henry}

by

\section{Rhys RICHARDS *}

In June 1822 at Tubuai, a tiny 40 ton brig captured a 300 ton brig of war armed with twenty cannons. The captured brig was formerly part of Lord Cochrane's squadron of patriots fighting the Spanish for the independence of Chile and Peru (see illustration). The losing captain, Henry Good, was long experienced in war before he turned to piracy. The victorious captain, Samuel Henry, was only 22 years old, totally inexperienced in war, and the son of Rev. William Henry, an Irish LMS missionary at Tahiti. Samuel Henry's enormous act of courage and heroism earned him no official recognition. Indeed this titanic victory of David against Goliath, of good against evil, was not even mentioned in the chronicle of the Tahitian Mission, apparently because the writer, John Davies, was so deeply engrossed in petty squabbles with Samuel's father (Newbury, 1961).

The events involved were well recorded by the Belgian trader J. A. Moerenhout, though largely it seems not from the perspective of Captain Henry, but rather from that of the volatile Irish first mate, Thomas Ebrill, who wrongly claimed all the credit for himself. Two unpublished letters in the State Archives of New South Wales now redress the balance somewhat by showing that in fact it was young Samuel Henry who led the capture of the pirate brig, and that Ebrill was not the leader.

In addition, up till now little has been available to Pacific historians about the preceding circumstances that led to the presence of this pirate ship at Tahiti and Tubuai as early as 1822 . This article now seeks to fill that gap briefly from Spanish records, and to draw attention to the two letters of explanation written by Samuel Henry soon after the events.

In December 1818 the British lord, Thomas Cochrane, became Admiral of the Chilean Navy. Late in 1819 Cochrane began a naval blockade of Callao, the port of Lima, which was then the Spanish capital of South America. Cochrane's fleet consisted of only seven vessels, all old, leaking and in poor repair (Thomas, 1978: 249). His crews were very mixed with a few politically motivated patriots, some Chilean Indians, but predominantly a core of European mercenaries intent upon seizing the fabled riches of the Spanish gold and silver mines.

As the blockade of Lima dragged on for many months, two vessels which had sustained damages were detached to raid Spanish settlements to procure whatever food they could find. These were the corvette Independencia with 44 guns under Captain Wilkinson and the Araucano with 28 guns under Captain Robert W. Simpson. Both captains were experienced in contraband trading along the Pacific coasts. Now Chile was in revolt, the English captains acted as if they were privateers, licensed by Chile to prey upon the Spanish enemy wherever they chose, and to seize any Spanish merchant ships trading along the coast.

In December 1821 Captain Simpson had taken the Araucano to Acapulco seeking food for the patriots attacking Lima, but the Governor of 
Mexico declined to permit any trade, detained Simpson for several days and then asked him to leave. In February 1822, trying again, both Captain Wilkinson and Captain Simpson sailed north, across the Equator to Baja California where they knew there were several small towns without any military presence. Captain Wilkinson seized a local merchant ship, and attacked the southernmost town of San Jose del Cabo, where his men stole everything they could including every item of any value in the church.

Captain Simpson took the Araucano further up the Gulf of Mexico to the town of Loreto, arriving on 17 February 1822. There his trading began peacefully, but when he found Loreto could not produce sufficient dried beef and flour, he took the ship's boat to visit Guyamas and other small towns nearby to see what food they might spare. During his absence, thirty of his crew mutinied, sacked Loreto, and occupied the looted church as their headquarters. Later on local Mexicans drove them out fiercely, capturing some. The remaining pirates retreated to their ship, where the first officer joined the mutineers and sailed off to Peru and Tahiti (Davis, 1980).

After further altercations and desertions, and unloading two boat's crews of unwanted Chileans and Indians on the coast of Peru, the Araucano reached Tahiti with barely enough crew to navigate, and leaking badly. At Tahiti they found many dissolute beachcombers ready to join a pirate ship. Also there laying at anchor was a replacement vessel, the small colonial brig Queen Charlotte under Captain Samuel Henry. He was born at Tahiti, was not only bilingual but also bi-cultural, and was highly regarded by both the Tahitians and the missionaries (though the latter deplored his "immorality" in sexual matters). Samuel was only 22 years old, but had already travelled widely across the south Pacific. Samuel had had some education in Sydney, including as a mechanic and in navigation so that he could take command of the mission's trading brig. Affable and well mannered, Samuel Henry was a protégé not only of Samuel Marsden but also of King Pomare I (Gunson, 1976: 36-45).

What followed when the pirates arrived at Tahiti in June 1822 is well covered by Moerenhout:

«The captain of the Araucano, or at least the man who called himself such, almost immediately after his arrival, repaired to the small ship, where he said that he was going to coast of New Zealand to fish for seals, offered Captain Henry some flour in exchange for several objects which he needed, and (a singular thing) finally succeeded after several days in dispelling any suspicion about whom he might be. It was only at the last moment that the insubordination of his crew gave rise to the thought that the pretended fisherman was a pirate.» (Borden, 1993: 455)

He told Henry that he was next bound northwards to the Marquesas to get supplies before sealing.

When Captain Henry took the Queen Charlotte out for Eimeo (Moorea) and Tubuai, he was startled that the Araucano (alias Prudence) followed, and tried to close with him near Eimeo. Samuel Henry evaded them, but was even more startled when he arrived at Tubuai only to find, to his "great surprise and fear», that the Araucano was anchored there already, as if waiting to prey upon him. The Queen Charlotte was only an eighth the size of the pirate, was totally outgunned and a sluggish sailor, and her crew of nineteen were greatly outnumbered. There certainly seemed no chance of an escape. Captain Henry wrote the following account:

«Shortly after I arrived, I was informed by an Englishman who had been on board the Prudence when I hove in sight that immediately on perceiving us, all hands on board her left their work, and loaded their guns with round and grape shot.

On the $22^{\text {nd }}$ June, Captain Patterson came on board and stated to me that there was a mutiny on board his vessel, and requested me to go on board as a protection to him, whilst he could make enquiry into the particulars, to which I acceded, taking with me Paihia, a chief, and a party of natives. Went on board where after some enquiries, Captain P. was obliged to relinquish the business not being able to find out the ringleaders; and a quarrel then ensuing between the crew, several words were made use of which appeared to me very suspicious, and caused me to question Captain P. closely. He appeared very much perplexed and alarmed, and in a confused manner hinted that things were not with him as they ought to be.

On $23^{\text {rd }}$ my chief mate [Ebrill] who had been on board the Prudence, came to me and stated that she was sailing under a false name, and that in reality she was a Patriot brig of war Arocano, formerly commanded by Captain Simpson, that she was run away with by Mr Patterson, who had been First Lieutenant on board of her, while Captain Simpson was on shore at Callao, with a great part of her crew, and that the person who called himself Patterson and now commanded her, was also under a false name, his proper name being Henry Good. He further stated to me that it was in agitation to take the Queen Charlotte as soon as she got outside the harbour, and put us on board the vessel, she being in such a damaged and leaky state that they would not remain in her themselves. This plan was objected to by some of their own people as we should in the event of being put on board of the Prudence, then be enabled to take the Queen Charlotte from them again. It was then agreed upon that they 
should throw all the guns overboard after taking us, and otherwise disable us in such a manner as should put it out of our power to molest them afterwards.

This statement from my Chief Mate naturally caused considerable alarm, which was further augmented when Mr Clark, First Officer of the Prudence, came on board the same day, and corroborated what my mate had stated and further added that I ought to be very much on my guard whilst in harbour. One of the crew of the Prudence, formerly the cook on the Queen Charlotte, also informed me of the plans that were laid to take her.

It was my intention to have sailed in the morning subsequent to this disclosure. But finding myself in such a critical situation with every chance of being pursued by the brig, from whom we could not possibly escape when out at sea as she had much superiority over using sailing and mounted eighteen guns with a large complement of men. I conceived it best under the circumstances of the case to consult with my crew, and having stated the particulars to them, they agreed to stand by me to a man, and endeavour to take the brig while she lay at anchor about a mile distant. The crew also stated that they had heard reports that alarmed them very much, as the brig was so well manned, and we were so few in number. It was finally agreed upon that when everything was in readiness we should take her.

Captain Patterson coming on board in the interim, I confined him and two men who accompanied him. Having in the meantime dispatched a boat for information, who returned after leaving two of their number on board, with word that part of the crew were on shore.

Upon this, I manned our [two] boats, and with myself, my mate, seven Europeans and ten Otaheitians, put off for the brig about $7 \mathrm{pm}$. On coming along side we boarded and took her without any lives being lost on either side or any damage done. At 10 o'clock I returned to my own vessel, leaving my chief mate in charge of the Prudence.» (Henry, Letter 1 July 1822)

According to Moerenhout, it was the new mate Thomas Ebrill, a lively Irishman, who first proposed that the best form of defence was a pre-emptive strike to capture the pirate ship whilst her crew were on shore and off guard (Borden, 1993: 456). This may be true, but the later reports by Henry make it absolutely clear that it was Henry himself who led the attack, supported by Ebrill. Henry is unlikely to have told untruths to his father, particularly since they would have been exposed by others on the Queen Charlotte on their return home.

At Tahiti, the foreign residents and the Tahitians alike were astonished that such a tiny ship had captured the big, well armed, ship of war. Captain Hunter of the Sydney brig Governor Macquarie later reported that:
«An English whaler, the name of which is not remembered by Captain Hunter, happening shortly after to touch at the islands, the captain of the captured brig with ten of his men, ran away in a boat and obtained a passage on board, thus effecting their escape, and satisfactorily proving their guilt of the charge of piracy attributed to them. Many actions subsequent to this capture, corroborated the statements in evidence against them. To act with all that prudence which should ever characterise British commanders in cases of such extreme importance, Captain Henry called a Council of four captains of whalers who had put in to refresh on their homeward bound passages. By this assembly the piratical brig was declared un-seaworthy; she therefore remains at Otaheite at anchor, and is already near akin to a wreck.» (Sydney Gazette 22 November 1822)

The members of the council of captains were probably Captain Hunter of the Governor Macquarie, Captain Walker of the Dragon, David Clark of the Good Hope and William Carlett of the John Bull. The Governor Macquarie was a pork trader; while the others were whaleships. The later British whaleship on which Captain Good and ten of his men left Tahiti was probably the Charles of London, Captain Lock.

Rather curiously no further record has been found of the pirate captain, whom Samuel Henry calls Henry Good, alias Henry Patterson. Nor is it known who else were among the pirate crew, but no doubt some at least continued to live in other Pacific islands as beachcombers, traders and tyrants.

\section{Moerenhout's account continues:}

«Unfortunately instead of leaving immediately with his capture for Chile, where honours and awards might await him, the noble victor, on the advice of the missionaries, left the brig at Tahiti waiting till it should be reclaimed by the Chilean Government, who were written to but never replied, whether for reason of the [ chaotic] state of the country, or whether the ship did not seem to them worth the effort.» (Borden, 1993: 457)

Samuel Henry's letter confirms the more mundane reason, namely that the Araucano was declared un-sea-worthy and left to rot. No doubt the wreck proved a major source of iron and brass for tool, weapons and other metal items for the local Tahitians whose previous reliance upon stone and wood was fast diminishing.

«Some years afterwards the Tahitians destroyed and appropriated the cannons, which are still on a small island in the center of Papeete...» (Borden, 1993: 457)

Afterwards Captain Ebrill went to Chile twice: 
«he even saw Simpson, the first captain of the brig, now commander of the Aquilles, but the Government paid no attention to him, and no-one spoke to him of his [sic-their] fine action [...] Ebrill was not even thanked [...]» (Borden, 1993: 463, 257)

Meanwhile in Chile the moment had passed as Lord Cochrane was no longer in command in 1823. So a leaky old ship requiring extensive repairs far away from repair facilities, was no great attraction. The Chileans too judged that the Araucano was best left to rot at Tahiti.

\section{Conclusion}

The two unpublished letters by Samuel Henry confirm the events and convey more of the context of Tahiti in 1822. The disunity and lawlessness among the various foreign visitors against each other, were conspicuous and in no way an encouragement for Tahitians to adopt foreign codes and mores uncritically. These letters also illustrate the disunity and dissent present among the foreign residents living ashore. Samuel Henry was unlikely to have written to tell his father untruths that might have been exposed on his return to Tahiti. Henry was brave but naive. Ebrill was a self-promoting opportunist ready to claim credit that belonged to Henry and, one suspects, Ebrill was not only a fast talker, but also a liar. Even the two recorders were biased: Moerenhout disliked the missionaries and the Henry family so much that he accepted Ebrill's biased reports. Davies was unwilling to endorse the bravery that had occurred because it was within the family of his fellow missionary, William Henry, with whom he was engrossed in petty squabbles. Only Captain Samuel Henry emerges well. He certainly deserves more credit and acclaim for his heroic David-and-Goliath victory over the war-seasoned pirates of the Araucano.

\section{Acknowlegements}

With thanks to Chris Maxworthy for locating the Spanish records and to Marion Minson for help with their translation. Also thanks to the State Archives of New South Wales for permission to use their letters by Samuel Henry.

\section{BIBLIOGRAPHY}

Borden A.R., 1993. Travels to the Islands of the Pacific Ocean, English translation of J.A. Moerenhout, Maryland.

Cochrane Lord Thomas, 1859. Narrative of Services in the Liberation of Chile, Peru and Brazil, vol. I, London.

Davis Estela, 1980. Corsarios chilenos en la California del sur, Revista (University of Baja California, Mexico), vol. 1, pp 1-14.

Gunson N., 1976. The Deviations of a Missionary Family: The Henrys of Tahiti, in A.H \& A.W Reed, Pacific Island Portraits, Auckland.

Henry S. P., ms. Letter to his father Rev W Henry: from the brig Queen Charlotte 1 July 1822: New South Wales State Archives, 4/1753, pp. 165a-165d [Microfilm reel 6052].

-, ms. Report to the Colonial Secretary, N.S.W. from the Ship Queen Charlotte in Sydney Cove 17 May 1823, New South Wales State Archives 4/1765, pp. 118-121 [Microfilm reel 6065].

Newbury Colin, 1961. The History of the Tahitian Mission 1799-1830, written by John Davies, edited by C.W. Newbury, Cambridge, Haklyut Society.

Sydney Gazette, 22 November 1822

Thomas Donald, 1978. Cochrane: Britannia's Last Sea-King, New York, Viking Press. 